\title{
Coffee Leaf Rust (Hemileia vastatrix) in Kenya-A Review
}

\author{
Elijah Gichuru *, Getrude Alwora, James Gimase (D) and Cecilia Kathurima \\ Coffee Research Institute, Kenya Agricultural and Livestock Research Organization, \\ Ruiru P.O. Box 4-00232, Kenya; alworahgetrude@gmail.com (G.A.); jgimase@gmail.com (J.G.); \\ cwkathurima@yahoo.com (C.K.) \\ * Correspondence: ekgichuru@gmail.com or elijah.gichuru@kalro.org
}

Citation: Gichuru, E.; Alwora, G.; Gimase, J.; Kathurima, C. Coffee Leaf Rust (Hemileia vastatrix) in Kenya-A Review. Agronomy 2021, 11, 2590. https://doi.org/10.3390/ agronomy 11122590

Academic Editor: Pedro Talhinhas

Received: 8 October 2021

Accepted: 30 November 2021

Published: 20 December 2021

Publisher's Note: MDPI stays neutral with regard to jurisdictional claims in published maps and institutional affiliations.

Copyright: (c) 2021 by the authors. Licensee MDPI, Basel, Switzerland. This article is an open access article distributed under the terms and conditions of the Creative Commons Attribution (CC BY) license (https:// creativecommons.org/licenses/by/ $4.0 /)$.

\begin{abstract}
Coffee is one of the most important cash crops and beverages in the world. Production of coffee is limited by many factors, which include insect pests and diseases, among others. One of the most devastating coffee diseases in many coffee-producing countries is Coffee Leaf Rust caused by the fungus Hemileia vastatrix. Kenya is a coffee-producing country and has conducted studies to understand and manage the disease. Management strategies for the disease include the development and use of fungicide spray programs, cultural control practices, breeding resistant coffee varieties, and biological control agents. This paper reviews the status of the disease and management options applied in Kenya.
\end{abstract}

Keywords: coffee; Kenya; Coffee Leaf Rust; races

\section{Introduction}

Coffee is an important crop and beverage in the world, creating incomes for over 125 million people. In terms of commerce, it is the second most traded commodity after oil [1]. Coffee is a tropical crop mainly grown in Southern America, Africa, Asia, and parts of Oceania primarily by smallholder farmers. In Africa, coffee is produced in Eastern, Central, and West Africa, with Ethiopia being the largest producer. It is also the origin of Arabica coffee (Coffea arabica) which is the main species produced in the world. Kenya produces Arabica coffee and is currently the fifth largest producer in Africa, down from being the second-largest producer in the 1980s [2-4]. Coffee in Kenya is produced in 32 counties by 800,000 smallholder farms and 6000 estates [2,5].

On the global scale, coffee production has been on a decline over the last two decades as compared to consumption which has been on a steady increase over the same period $[1,6,7]$. The recent decline has mainly been attributed to the Coffee Leaf Rust, Hemilleia vastatrix Berk. and Br. (CLR) outbreak that hit most coffee-producing countries in 2008-2011 [8-11]. Other challenges facing coffee production include climate change, insect pests, other coffee diseases, volatile prices, soil fertility management, competition from other enterprises, aging farmers, and high costs of production [4].

Coffee Leaf Rust is a major disease of Arabica coffee, causing significant economic losses and has been reported in over fifty (50) coffee-growing countries [12]. The disease can cause yield losses in excess of 75\% where outbreaks are severe [13] due to loss of foliage by up to $100 \%$ and loss of berries by up to $70 \%$ [14]. The disease cause losses of one to two billion US dollars annually [15]. Since 1976 when the disease was observed in Central America, the worst was the recent epidemic affecting all countries in the region, during which a 53\% incidence was experienced. The first case of CLR in Kenya was reported in 1912, though records indicate that it was noticed in 1861 near Lake Victoria (western Kenya) on wild coffee [16]. This indicated that the pathogen was infecting other Coffea species before the introduction of Arabica coffee in Kenya.

Coffee in Kenya is mainly grown in two regions, the East of Rift Valley (areas around Mount Kenya, the Aberdare ranges, and Machakos) and West of Rift Valley (Kisii highlands, 
area around Mt Elgon and the North of the Rift valley) [17,18]. In the East of the Rift valley, the distribution of rainfall is bimodal with two distinct rainy seasons, where the peak of the first one is in April and the second peak in November [19] while the converse is true for the eastern part of the country. The West of the Rift Valley experiences a bimodal rainfall distribution with the peak of the long rains occurring in the months of March-May and the short rains in September-December while some areas have a third minor peak during the months of June-July-August [20]. These weather patterns affect the epidemics of CLR with the peak of the disease coming soon after the rainy seasons when it fully sporulates from latent infections that occur during the rainy season, but they sporulate when temperatures rise after the rains [21,22].

Understanding and managing CLR has been a focus of research internationally for a long and the recent devastating effects of the disease, coffee-growing countries have enhanced efforts to initiate more research aimed at alleviating the threat of leaf rust through their national research institutions, partners, and international research centers [23]. This review paper provides an insight into research efforts made into understanding the biology of the pathogen, efforts done in Kenya in breeding for CLR resistant coffee varieties, and other management practices adopted.

\section{History and Spread of CLR}

Coffee Leaf Rust (CLR) was reported in 1869 in Ceylon (now Sri Lanka) and by the 1920s, it had spread to most parts of Africa and Asia [24,25]. Towards the end of the nineteenth century, CLR caused severe damage to the coffee plantations of Sri Lanka, the Philippines, Java (an island in Indonesia), and Malaya (now part of Malaysia), which led to the collapse of the coffee industry in the region [26]. The disease was detected in the Americas in 1960, and until recently, it caused losses of $20-25 \%$ per annum in some regions [27]. In late 2012, it emerged in Mesoamerica, the Northern part of South America, and the Caribbean as a significant threat to coffee production with yield losses predicted to reach 50\% for the 2013 harvest season [28].

In Kenya, CLR was first reported in 1912 [11] but it was not serious until 1954 [11]. However, there are chronicles that it was observed in 1861 in Western Kenya near Lake Victoria on uncultivated coffee [29], an indication that this disease probably existed earlier in Eastern Africa without causing epidemics or considerable loss on certain coffee varieties or species. Possibly, the co-existence between coffee and rust for a long period might have kept the rust infection at low levels [9]. The disease has been a major threat to the production of coffee in the lower coffee-growing areas of Kenya but is increasingly being observed in higher altitudes due to climate change [30].

\section{Taxonomy and Biology of CLR Pathogen}

Coffee Leaf Rust is caused by the fungus Hemileia vastatrix which was first described by Berkeley and Broome in 1869 [9] and is classified as follows: Phylum: Basidiomycota, Subphylum: Pucciniomycotina, Class: Pucciniomycetes, Order: Pucciniales, Family: Incertae sedis, Genus: Hemileia. Hemileia vastatrix (Berkeley and Broome) is an obligate-host-specific pathogen characterized by a powdery coating of yellow urediniospores on the underside of the coffee leaves [31].

Through international collaborations coordinated by the Coffee Rusts Research Centre (CIFC, (Centro de Investigacao das Ferrugens do Cafeeiro) in Portugal, detailed studies on CLR have been undertaken with several genes for resistance and compatibility described in detail in the host and the pathogen respectively [29]. Studies have shown that at least nine resistance genes $\left(\mathrm{S}_{\mathrm{H}} 1-\mathrm{S}_{\mathrm{H}} 9\right)$, confer resistance of coffee plants to CLR either singly or in combination [32]. In C. arabica $\mathrm{S}_{\mathrm{H}} 1, \mathrm{~S}_{\mathrm{H}} 2, \mathrm{~S}_{\mathrm{H}} 4$, and $\mathrm{S}_{\mathrm{H}} 5$ have been found while $\mathrm{S}_{\mathrm{H}} 6, \mathrm{~S}_{\mathrm{H}} 7$, $\mathrm{S}_{\mathrm{H}} 8$, and $\mathrm{S}_{\mathrm{H}} 9$, were introgressed from the diploid species $C$. canephora. The $\mathrm{S}_{\mathrm{H}} 3$ which provides durable resistance originated probably from C. liberica. Intense studies have also been done on the pathogen diversity to identify its races. Only six races of the pathogen (I, II, VII, XV, XX, and XXIV) had been reported in Kenya up to the year 2012 when six 
additional races (III, XVII, XXIII, XXXVI, XLI, and XLII) were reported [29]. The new races confirmed the presence of three new virulence genes (v1, v7, v8) and a possible fourth one, (the v9) but these races are not widespread [29]. Currently, more diversity studies are ongoing at Coffee Research Institute, Ruiru Kenya as part of international collaborative efforts to understand the pathogen. The continuous increase in the number of races of the pathogen is a major threat to coffee production and could cause a drawback to the progress made in breeding for resistance in Kenya and worldwide.

\section{Epidemiology}

Hemileia vastatrix requires temperatures of $10{ }^{\circ} \mathrm{C}$ to $35^{\circ} \mathrm{C}$ and water to develop $[33,34]$. Rust development is affected by temperatures with temperatures below $15^{\circ} \mathrm{C}$ hampering spore germination and slowing down growth while temperatures above $35^{\circ} \mathrm{C}$ slow down fungal growth. Uredinial germination and infection require about 24 to $48 \mathrm{~h}$ of continuous free moisture. The most optimal temperature for the growth and proliferation of the rust is between $21-25^{\circ} \mathrm{C}$ with 100 percent Relative Humidity [35]. Weather patterns affect the epidemics of CLR with the peak of the disease coming soon after the rainy seasons when it fully sporulates from latent infections that occur during the rainy season but sporulate when temperatures rise after the rains [21]. The peaks of rainfall pattern therefore always correlate to CLR infection peaks with the peaks of the disease occurring immediately after the peak of the rains.

In Kenya, coffee-growing regions are broadly classified into West of Rift and East of Rift regions and the seasonal variability of the disease in the regions has been established. In areas West of Rift, the long rains start in March through August while the short rains start in September through November and this corresponds to two CLR peaks in June to July and October to December. In areas East of Rift, the long rains start in March through May and short rains start in October through December resulting in two CLR peaks in May to June and January to March [20,21,36]. Rainfall distribution is more influential in the progression of the disease whereby light and broken rain is more favorable than continuous rain $[8,34,37]$. The spread of the disease within a farm is mainly by rain splash and reduction of the infectivity of the spores at the start of rains can greatly reduce the development of an epidemic [33]. Wind and human activity may play a higher role in introducing the disease in new areas but insects may also play a role [38]. Unseasonal rainfall resulted in a longer period of disease progression that produced more disease later and the peaks of the disease could be traced to individual rainfall periods [39].

Further, [21] identified the three factors that affect the course of the disease when rainfall is not limiting as (i) the intensity and distribution of the rainfall (ii) residual inoculum at the troughs, and (iii) the leafiness of the tree with heavily foliated trees having more rust particularly at low inoculum levels.

Young lesions may appear as small chlorotic spots before sporulation occurs (Figure 1). Yellow to orange powdery blotches appear on the underside of leaves, with corresponding chlorotic patches on the upper side. Initially, these are only 2-3 mm diameter, but steadily expand, coalesce, the centers of older lesions become necrotic and the sporulating zone is restricted to the outermost zone (Figure 2). On older leaves, several lesions may merge to produce irregular diseased areas covering much of the leaf. Occasionally, rust lesions occur on young green stems and berries [25,40]. The major effect of CLR is defoliation (Figure 3) which reduces the photosynthetic area [41]. Photosynthesis provides the most essential carbohydrates for the proper metabolic functioning of plants and any disease adversely affecting the leaves affects production negatively [15,25]. A heavy CLR infestation of leaves not only reduces the assimilation area but can also result in complete defoliation [42] leading to dieback and a loss in both yield and quality. Defoliation, by reducing the growth potential of the plant, restricts the growth of new stems on which the following season's crop would be produced [43]. 


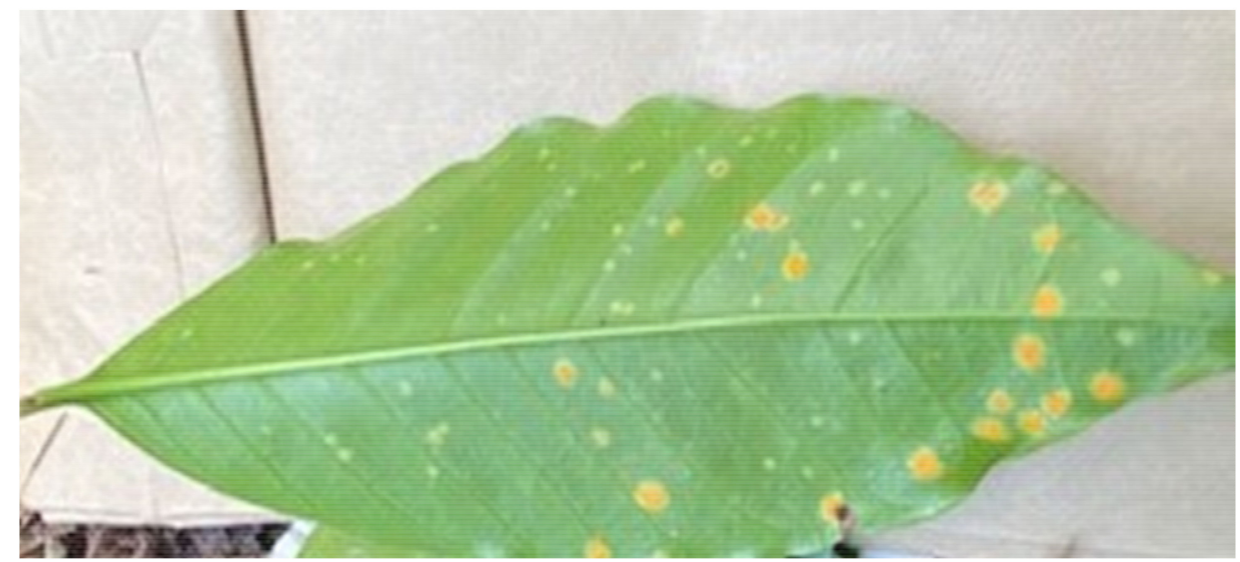

Figure 1. Young orange to yellow lesions of Coffee Leaf Rust on the underside of a coffee leaf.
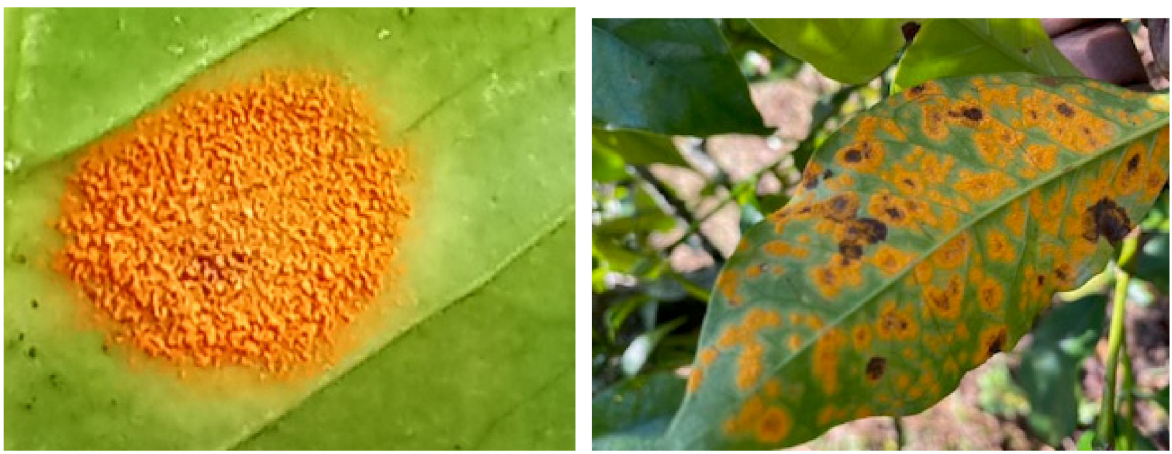

Figure 2. An active fully expanded CLR Lesion (left) and advanced stages of Coffee Leaf Rust infection showing coalesced lesions and necrotic centers (right).

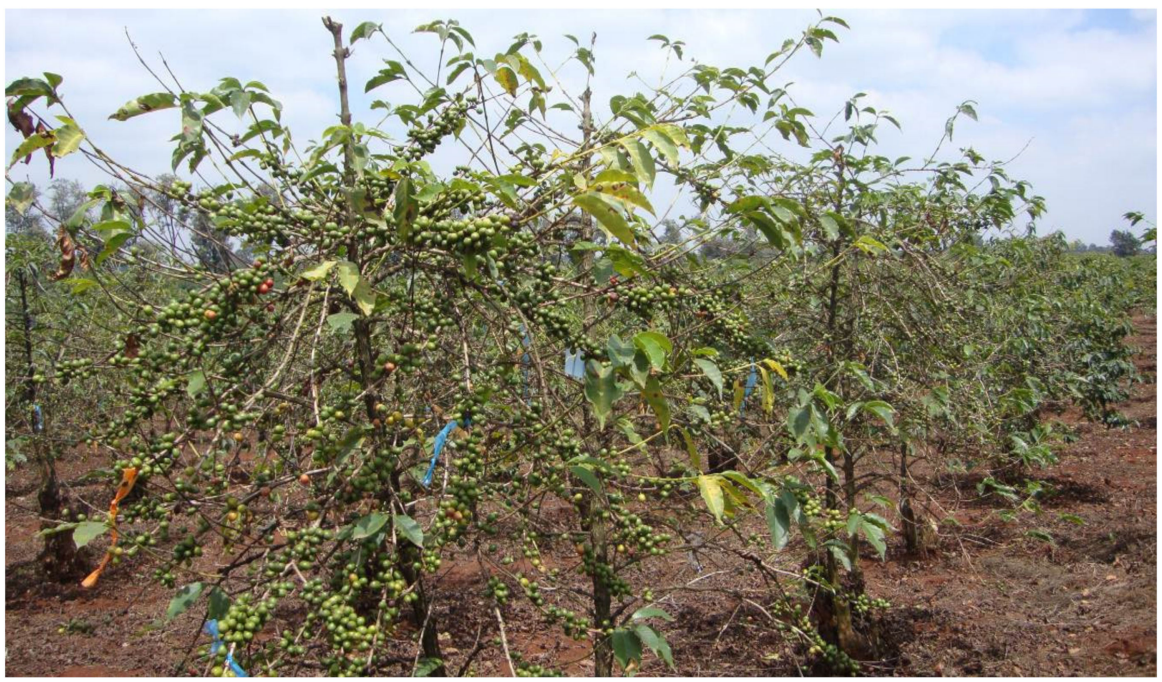

Figure 3. Coffee trees defoliated due to Coffee Leaf Rust infection.

\section{Management of CLR in Kenya}

Effective management of CLR is of utmost importance in sustained production and productivity of coffee [44] and the use of fungicides was the earliest adopted in Kenya [45]. Currently, the use of cultural practices, planting resistant varieties, and application of contact and systemic fungicides are the most adopted practices among farmers [14,46-48]. Efforts continue to be made to reduce the reliance on chemical control and only consider it as the last resort because it is expensive and injurious to humans and the environment. The status of the management options practiced by coffee producers in Kenya is discussed below. 


\subsection{Resistant Varieties}

The growing of resistant coffee varieties has always been considered the most sustainable and affordable management of CLR [49]. In Kenya, the development of CLR-resistant coffee varieties can be traced as far back as the 1920s when selection for disease resistance/tolerance, high yields, and quality was started [32]. This led to the release of the first Kenyan coffee varieties (SL28, SL34, and K7) in the 1930s which had high yields and good cup quality but were susceptible to coffee berry disease, leaf rust, and bacterial halo blight of coffee (Pseudomonas syringae pv. garcae). Further studies indicated that K7 had tolerance to some races of CLR as well as partial resistance to CBD [50].

After a severe outbreak of CBD and CLR in the late 1960s, a breeding program for disease resistance was started in 1971. The program aimed at developing varieties that combine resistance to CBD and CLR coupled with high yields and beverage quality culminating in the release of the variety Ruiru 11 in 1985 [49] and later Batian in 2010 [9]. The cultivar Ruiru 11 is a composite of $66 \mathrm{~F} 1$ hybrid sibs each derived from crosses between specific female and male populations [9]. The male parents are tall statured selections from multiple crossbreeding programs involving the Coffee Berry Disease (CBD) resistant donor parents Rume Sudan (R gene), Hibrido de Timor (T gene), K7 (k gene), and the susceptible high yielding good quality cultivars N39, SL28, SL34, Bourbon, and SL4 [49]. The female parents are short compact advanced generations (F3, F4, and F5) of the Colombian cultivar Catimor (a hybrid between Caturra rojo and Hibrido de Timor clone 1343/269 [49]. Batian is true to type variety selected from three breeding lines of the male parents of Ruiru 11 after a series of selfing to fix the CBD resistant genes. The development of durable resistance is hampered by the high variability of the CLR pathogen [50], but the development of resistant coffee varieties continues to be a priority in Kenya [51]. Ruiru 11 has remained highly resistant to CLR since its release while Batian exhibits intermediate resistance to CLR.

\subsection{Cultural Practices}

Cultural control is the deliberate modification of crop-production systems, to reduce pest populations or avoid pest injury to crops. Cultural practices that have been adopted by farmers in Kenya to manage CLR include but are not limited to mixed-cropping with fruit trees, shade trees, and maintenance pruning of the coffee trees [52,53]. Studies have shown that CLR incidences and severity were lower on intensively grown coffee trees than on those grown traditionally [54]. Pruning plays a major role in the management of CLR as it reduces the tree foliage increasing air circulation between branches thus modifying the within tree microclimate. This causes rapid evaporation resulting in reduced periods of leaf wetness, a key factor in spore germination. Further, management of the tree architecture increases nutrient and water use efficiency resulting in healthier plants, as well as increasing the efficiency of chemical sprays by enhancing spray penetration. Canopies of shade trees can also lower CLR levels by intercepting and reducing the energy of raindrops, diverting others from their trajectory as they approach the coffee trees. Therefore the raindrops that fall onto coffee trees via foliage of shade plants might not be energetic enough to dislodge and disperse conidia [55].

Studies in Kenya showed that coffee bushes under shade retained the infected leaves for significantly longer periods than coffee in the open sun while the disease severity was significantly higher in the trees in shade than in open sun [56]. The pattern is affected by distance from the shade tree hence the intensity of shade and the amount of rain since light rains do not wet coffee in shade as much as that in the open [57]. These findings underscore the complexity of the progression of CLR in coffee agro-systems as discussed by [58].

Proper and timely pruning is adopted by most coffee farmers in Kenya as a strategy to manage CLR. Coffee Research Institute has developed an elaborate coffee canopy management guideline that is accessible to all farmers [36]. This guideline emphasizes that pruning and shading is a critical integral cultural practice for the control of CLR. Other research work has reported that shade could alter the microclimate and soil properties within coffee plantations, which directly or indirectly affects pest incidences and development $[23,58]$. 
Though shade has been linked to positive gains in the management of various pests, it is essential to consider its contribution to an increase or decrease in coffee diseases which can be region dependent. Proper shading is critical, as the resulting microclimate alterations may favor one species or stage of development or could be unfavorable to another species or developmental stage [59]. The use of shade to manage coffee pests and diseases is thus done by considering all pests present, to find the shading balance point where desired ecological control mechanisms are promoted, adverse effects are minimized, and farmer's preference is incorporated.

\subsection{Biological Control}

Biological control involves the use of whole or parts of living organisms to lower the population of pests [60]. Studies on biological control of CLR have been ongoing for several decades $[31,61,62]$. Despite numerous studies on the biological control of CLR, there are very limited classical applications of biocontrol agents in Kenya. Commercial production of biologically based products for the management of CLR in Kenya has also been very insignificant. There is currently only one product that has been tested, approved, and is commercially available for use by farmers, Serande ASO ${ }^{\circledR}$ consisting of Bacillus subtilis strain QST $7131.34 \% w / w$. Despite the slow uptake of biological control at the farm level, successful laboratory studies have isolated and identified potential biocontrol agents that can be used to manage CLR. Studies in this area are ongoing at Coffee Research Institute, Kenya.

\subsection{Chemical Control}

Coffee Leaf Rust is effectively managed by timely application of fungicides and their use in Kenya started in 1960 [44]. The fungicides that are currently registered for use to manage the disease in Kenya are listed on the Pest Control Products Board (PCPB) website and the list is frequently updated (https:/ / www.pcpb.or.ke, accessed on 25 November 2021). Timely application of chemical control is critical in its success as it largely depends on the disease-pathogenesis stage at the moment when the fungicide is applied [63]. Copper-based fungicides such as Bordeaux and Burgundy mixtures were established to manage CLR by the last decade of the 19th century $[45,64]$. Cuprous oxide is still being used in many formulations such as Nordox 50WP, Nordox Super 75WP, and Nordox 75WG [36]. Copper hydroxide (commonly known as blue copper) and Copper oxychloride (Green copper) were later introduced to manage CLR [64,65] while more recently, copper sulfate has been introduced. The main chemical families are coppers, Iprodione, Vinclozolin, and Chlorothalonil Benzimidazoles (Thiabendazole), sterol inhibitors (Triadimefon, Cyproconazole, Hexaconazole, and Propiconazole), and the most recently introduced Strobilurin (Trifoxystrobin, Pyraclostrobin, and Azoxystrobin) [63]. The use of these compounds needs to be alternated to avoid the development of tolerant strains of the pathogen as was found early in the management of Coffee Berry Disease (CBD) using benzimidazole in Kenya [66]. Furthermore, there is a wave of banning various pesticides as more information on their effects on humans, ecosystems, and the environment is being reported and countries adopt different assessment methods [67].

Before a fungicide is introduced into the Kenyan market for use in coffee, Coffee Research Institute (CRI) undertakes field efficacy trials for the management of CLR on behalf of the Pest Control Products Board (PCPB). After evaluation, PCPB uses the CRI report to register the fungicide and provides farmers with a list of registered products, indicating the recommended rates as well as the proper timing of application. Following the rainfall patterns in the main coffee growing regions, fungicide sprays for CLR control in Kenya starts in mid-October, just before the start of short rains followed by a second spray, three weeks after the first spray $[35,44]$. These two sprays reduce the production of new spores leading to low inoculum potential at the beginning of the long rains [67]. For the long rain period, the first spray is applied in late February or early March followed by one or two sprays at three weeks intervals for copper formulations and four-week intervals for 
other formulations. Systemic formulations are applied only twice in a season to reduce the risk of the development of resistance. However, the spray program needs to be monitored and varied in response to weather patterns [67] because climate change is affecting the rainfall amounts and distribution.

\section{Conclusions}

Coffee Leaf Rust is a major threat to profitable and sustainable coffee production all over the world. Research work at national and international levels continues to provide options for managing the disease but new challenges do arise. These include global warming that makes hitherto unsuitable areas to be suitable for the disease, breaking of host resistance, customer, and environmentalists' demand for reduced use of fungicides, and potential tolerance of the pathogen to some fungicides. More work is required to keep abreast with the dynamics of the disease and develop more options such as biological control to manage the disease. It remains a constant concern that the pathogen may break the resistance of the two resistant varieties released for commercial production in Kenya. Integrated disease management combining resistant varieties, biological control agents, cultural practices, and judicious chemical control will offer an effective and sustainable CLR management strategy. Future research focus needs to address the above issues to sustain the productivity and profitability of coffee farming. This is best achieved in an integrated approach in managing the disease with an international exchange of knowledge and biological materials.

Funding: This research received no funding.

Institutional Review Board Statement: Not applicable.

Informed Consent Statement: Not applicable.

Data Availability Statement: Not applicable.

Acknowledgments: This paper is published with the permission of the Institute Director, Coffee Research Institute (CRI) on behalf of the Director-General of Kenya Agricultural and Livestock Research Organization (KALRO). The authors are grateful to the reviewers and editors of this paper for their critical and insightful inputs.

Conflicts of Interest: The authors declare no conflict of interest.

\section{References}

1. United States Department of Agriculture. Coffee: World Markets and Trade; USDA Foreign Agricultural Service: Washington, DC, USA, 2019; Available online: https://downloads.usda.library.cornell.edu/usda-esmis/files/m900nt40f/xk81jw68v/kp78gs60d/ coffee.pdf (accessed on 11 January 2021).

2. Gitonga, K.; Snipes, K. Kenya: Coffee Annual Report. USDA Foreign Agricultural Service, GAIN Report; pp. 1-4. Available online: https:/ / gain.fas.usda.gov/RecentGAINPublications/CoffeeAnnual_Nairobi_Kenya_5-13-2016.pdf2015 (accessed on 25 November 2021).

3. Monroy, L.; Mulinge, W.; Witwer, M. Analysis of Incentives and Disincentives for Coffee in Kenya; Technical Notes Series; MAFAP, FAO: Rome, Italy, 2013.

4. ICC. Assessing the economic sustainability of coffee growing. In Proceedings of the International Coffee Council 117th Session, London, UK, 19-23 September 2016.

5. International Coffee Organization. Country Coffee Profile: Kenya. In Proceedings of the International Coffee Council 124th Session, Nairobi, Kenya, 25-29 March 2019.

6. Daba, G.; Helsen, K.; Berecha, G.; Lievens, B.; Debela, A.; Honnay, O. Seasonal and altitudinal differences in Coffee Leaf Rust epidemics on coffee berry disease-resistant varieties in Southwest Ethiopia. Trop. Plant Pathol. 2019, 44, 244-250. [CrossRef]

7. Hindorf, H.; Omondi, C.O. A review of three major fungal diseases of Coffea arabica L. in the rainforests of Ethiopia and progress in breeding for resistance in Kenya. J. Adv. Res. 2011, 2, 109-120. [CrossRef]

8. Liebig, T.I. Abundance of Pests and Diseases in Arabica Coffee Production Systems in Uganda-Ecological Mechanisms and Spatial Analysis in the Face of Climate Change. Ph.D. Thesis, Leibniz Universität Hannover, Hannover, Germany, 2017.

9. Talhinhas, P.; Batista, D.; Diniz, I.; Vieira, A.; Silva, D.; Loureiro, A.; Tavares, S.; Pereira, A.P.M.C.; Gil Azinheira, H.; GuerraGuimarães, L. The Coffee Leaf Rust pathogen Hemileia vastatrix: One and a half centuries around the tropics. Mol. Plant Pathol. 2017, 18, 1039-1051. [CrossRef] [PubMed] 
10. Prabhakaran, N.K.P. Coffee. In The Agronomy and Economy of Important Tree Crops of the Developing World; Prabhakaran Nair, K.P., Ed.; Elsevier Press: London, UK, 2010; pp. 181-206.

11. Silva, M.D.C.; Várzea, V.; Guerra-Guimarães, L.; Gil Azinheira, H.; Fernandez, D.; Petitot, A.-S.; Bertrand, B.; Lashermes, P.; Nicole, M. Coffee resistance to the main diseases: Leaf rust and coffee berry disease. Braz. J. Plant Physiol. 2006, 18, 119-147. [CrossRef]

12. Rutherford, M.A.; Phiri, N. Pests and Diseases of Coffee in Eastern Africa: A Technical and Advisory Manual; CAB International: Wallingford, UK, 2006.

13. Bebber, D.P.; Castillo, Á.D.; Gurr, S.J. Modelling Coffee Leaf Rust risk in Colombia with climate reanalysis data. Philos. Trans. R. Soc. B 2016, 371, 20150458. [CrossRef]

14. McCook, S. Global rust belt: Hemileia vastatrix and the ecological integration of world coffee production since 1850. J. Glob. Hist. 2006, 1, 177-195. [CrossRef]

15. Wellman, F.L. Americans face up to the threat of coffee rust. Foreign Agric. 2021, 17, 1-7.

16. Kathurima, C. Characterization of Coffee Genotypes in Kenya by Genetic, Biochemical and Beverage Quality Profiles. Ph.D. Thesis, Jomo Kenyatta University of Technology, Juja, Kenya, 2013.

17. Gimase, J.M.; Thagana, W.M.; Omondi, C.O.; Ithiru, J.M. Evaluation of Coffee Berry Disease resistance (Colletotrichum kahawae) in F2 populations derived from Arabica coffee varieties Rume Sudan and SL 28. J. Plant Breed. Crop. Sci. 2019, 11, $225-233$.

18. Jaetzold, R.; Schmidt, H.; Hrnetz, B.; Shisanya, C. Farm Management Handbook Vol II, Part C, East Kenya. Subpart C1, Eastern Province; Ministry of Agriculture: Nairobi, Kenya, 2006.

19. Wakachala, F.M.; Shilenje, Z.W.; Nguyo, J.; Shaka, S.; Apondo, W. Statistical Patterns of Rainfall Variability in the Great Rift Valley of Kenya. J. Environ. Agric. Sci. 2015, 5, 17-26.

20. Bock, K.R. Seasonal periodicity of Coffee Leaf Rust and factors affecting the severity of outbreaks in Kenya Colony. Trans. Br. Mycol. Soc. 1962, 45, 289-300. [CrossRef]

21. Muthappa, B.N. Behaviour of Hemileia vastatrix during unfavourable weather. J. Coffee Res. 1980, 10, 31-35.

22. Avelino, J.; Willocquet, L.; Savary, S. Effects of crop management patterns on coffee rust epidemics. Plant Pathol. $2004,53,541-547$. [CrossRef]

23. Nutman, F.J.; Roberts, F.M. Coffee Leaf Rust. PANS 1970, 16, 607-624. [CrossRef]

24. Waller, J.M. Coffee rust-epidemiology and control. Crop Prot. 1982, 1, 385-404. [CrossRef]

25. Almeida, F.; Rodrigues, M.L.; Coelho, C. The still underestimated problem of fungal diseases worldwide. Front. Microbiol. 2019, 10, 1-5. [CrossRef]

26. Huerta-Espino, J.; Singh, R.P.; Germán, S.; McCallum, B.D.; Park, R.; Chen, W.Q.; Bhardwaj, S.C.; Goyeau, H. Global status of wheat leaf rust caused by Puccinia triticina. Euphytica 2011, 179, 143-160. [CrossRef]

27. Avelino, J.; Cristancho, M.; Georgiou, S.; Imbach, P.; Aguilar, L.; Bornemann, G.; Läderach, P.; Anzueto, F.; Hruska, A.J.; Morales, C. The coffee rust crises in Colombia and Central America (2008-2013): Impacts. plausible causes and proposed solutions. Food Secur. 2015, 7, 303-321. [CrossRef]

28. Gichuru, E.K.; Ithiru, J.M.; Silva, M.C.; Pereira, A.P.M.C.; Várzea, V.M. Additional physiological races of Coffee Leaf Rust (Hemileia vastatrix) identified in Kenya. Trop. Plant Pathol. 2012, 37, 424-427. [CrossRef]

29. CIAT. Climate Change Adaptation and Mitigation in the Kenyan Coffee Sector Final Report; CIAT: Cali, Colombia, 2010.

30. Muller, R.A.; Berry, D.; Avelino, J.; Bieysse, D. Coffee Diseases; Wiley-VCH: Weinheim, Germany, 2008.

31. Gichimu, B.M. Coffee Breeding in Kenya: Achievements, Challenges and Current Focus. In Proceedings of the 24th International Conference on Coffee Science, San José, Costa Rica, 12-16 November 2012.

32. Waller, J.M.; Bigger, M.; Hillocks, R.J. Coffee Diseases and Their Management. In Coffee Pests, Diseases and their Management; CABI: Wallingford, UK, 2007; pp. 1-434.

33. Mayne, W.W. Seasonal periodicity of Coffee Leaf Rust (Hemileia vastatrix B. \& Br.), Second report. Coffee Exp. Stn. BulL 1931, 6, $1-25$.

34. Nutman, F.; Roberts, F.; Clarke, R. Studies on the biology of Hemileia vastatrix Berk. \& Br. Trans. Br. Mycol. Soc. 1963, 46, 27-44.

35. CRI. Coffee Production Recommendations; KALRO: Nairobi, Kenya, 2016.

36. Mayne, W.W. A note on the origin of attacks by leaf disease (Hemileia vastatrix) on coffee estates. Plant Chron. 1939, 34, 14.

37. Crowe, T.J. Possible insect vectors of Hemileia vastatrix in Kenya. Trans. Brit. Mycol. Soc. 1963, 46, 24-26. [CrossRef]

38. Rayner, R. Leaf Rust. In Kenya Coffee; Coffee Board of Kenya: Nairobi, Kenya, 1956; pp. 20-21.

39. Gichuru, E.K. Management of Main Coffee Diseases in Kenya. In Proceedings of the International Coffee Symposium, Belo Horizonte, Brazil, 11 June 2013.

40. Toniutti, L.; Breitler, J.C.; Etienne, H.; Campa, C.; Doulbeau, S.; Urban, L.; Lambot, C.; Pinilla, J.H.; Bertrand, B. Influence of Environmental Conditions and Genetic Background of Arabica Coffee (C. arabica L) on Leaf Rust (Hemileia vastatrix) Pathogenesis. Front. Plant Sci. 2017, 8, 2025. [CrossRef]

41. Yirga, M. Potential Effects, Biology and Management Options of Coffee Leaf Rust (Hemileia Vastatrix): A Review. Int. J. For. Hortic. 2020, 6, 19-31.

42. Clifford, M. Coffee: Botany, Biochemistry and Production of Beans and Beverage; Croom Helm Ltd: London, UK, 1985 ; p. 22.

43. Alwora, G.O.; Gichuru, E.K. Advances in the Management of Coffee Berry Disease and Coffee Leaf Rust in Kenya. J. Renew. Agric. 2014, 2, 5. [CrossRef] 
44. Bock, K. Control of Coffee Leaf Rust in Kenya Colony. Trans. Br. Mycol. Soc. 1962, 45, 301-313. [CrossRef]

45. Daivasikamani, S. Biological control of Coffee Leaf Rust pathogen, Hemileia vastatrix Berkeley and Broome using Bacillus subtilis and Pseudomonas fluorescens. J. Biopestic. 2009, 2, 94-98.

46. Manso, G.L.; Knidel, H.; Krohling, R.A.; Ventura, J.A. A smartphone application to detection and classification of coffee leaf miner and Coffee Leaf Rust. arXiv 2019, arXiv:1904.00742v1. Available online: https:/ /arxiv.org/pdf/1904.00742.pdf (accessed on 25 May 2021).

47. Mengistu, A.D.; Alemayehu, D.M.; Mengistu, S.G. Ethiopian Coffee Plant Diseases Recognition Based on Imaging and Machine Learning Techniques. Int. J. Database Theory Appl. 2016, 9, 79-88. [CrossRef]

48. Omondi, C.; Ayiecho, P.; Mwang'Ombe, A.; Hindorf, H. Resistance of Coffea arabica cv. Ruiru 11 tested with different isolates of Colletotrichum kahawae, the causal agent of coffee berry disease. Euphytica 2001, 121, 19-24. [CrossRef]

49. van der Vossen, H.A.M.; Walyaro, D.J. Breeding for resistance to Coffee Berry Disease in Coffea arabica L. Inheritance of the resistance. Euphytica 1980, 29, 77-91. [CrossRef]

50. Várzea, V.M.P.; Marques, D.V. Population Variability of Hemileia vastatrix vs. Coffee Durable Resistance. In Durable Resistance to Coffee Leaf Rust; UFV: Viçosa Brazil, 2005; pp. 53-74.

51. Gichuru, E.K. Coffee Research in Kenya: Current and Future Perspective in Coffee: A Comprehensive Guide to Bean, the Beverage, and the Industry; Rowman and Littlefield Publishers: Lanham, MD, USA, 2013.

52. Staver, C.; Guharay, F.; Monterroso, D.; Muschler, R.G. Muschler, Designing pest-suppressive multistrata perennial crop systems: Shade-grown coffee in central America. Agrofor. Syst. 2001, 53, 151-170. [CrossRef]

53. Panthi, B.B. Small scale Coffee Farmer's Response towards Management of Coffee Pest through Field Level Techniques. J. Inst. Sci. Technol. 2015, 19, 37-44. [CrossRef]

54. Garedew, W.; Lemessa, F.; Pinard, F. Landscape context and plot features influence the epidemics of Coffee Leaf Rust (Hemileia vastatrix) in southwest Ethiopia. Arch. Phytopathol. Plant Prot. 2019, 52, 71-89. [CrossRef]

55. Alwora, G.O.; Gichuru, E.K.; Pinard, F. Effect of shade on the severity of Coffee Leaf Rust. In Proceedings of the 25th International Conference on Coffee Science, ASIC 2014, Armenia, Colombia, 8-13 September 2014.

56. Mayoli, R.; Gichuru, E.K. Epidemiology of Coffee Leaf Rust: Influence of shade on microclimate and ecophysiology of coffee. In Proceedings of the 24th International Conference on Coffee Science, San José, Costa Rica, 12-16 November 2012.

57. López-Bravo, D.; Virginio-Filho, E.D.M.; Avelino, J. Shade is conducive to coffee rust as compared to full sun exposure under standardized fruit load conditions. Crop Prot. 2012, 38, 21-29. [CrossRef]

58. Avelino, J.; Romero-Gurdián, A.; Cruz-Cuellar, H.F.; Declerck, F.A.J. Landscape context and scale differentially impact Coffee Leaf Rust, coffee berry borer, and coffee root-knot nematodes. Ecol. Appl. 2012, 22, 584-596. [CrossRef]

59. Aristizábal, L.F.; Johnson, M.; Shriner, S.; Hollingsworth, R.; Manoukis, N.C.; Myers, R.; Bayman, P.; Arthurs, S.P. Integrated pest management of coffee berry borer in Hawaii and Puerto Rico: Current status and prospects. Insects 2017, 8, 123. [CrossRef]

60. Jackson, D.; Skillman, J.; Vandermeer, J. Indirect biological control of the Coffee Leaf Rust, Hemileia vastatrix, by the entomogenous fungus Lecanicillium lecanii in a complex coffee agroecosystem. Biol. Control 2012, 61, 89-97. [CrossRef]

61. Shiomi, H.F.; Silva, H.S.A.; de Melo, I.S.; Nunes, F.V.; Bettiol, W. Bioprospecting Endophytic Bacteria for Biological Control of Coffee Leaf Rust Bioprospecção De Bactérias Endofíticas Como Agentes De Biocontrole Da Ferrugem Do Cafeeiro. Sci. Agric. 2006, 63, 32-39. Available online: http:/ /www.scielo.br/pdf/sa/v63n1/27900.pdf (accessed on 30 January 2021). [CrossRef]

62. Zambolim, L. Current status and management of Coffee Leaf Rust in Brazil. Trop. Plant Pathol. 2016, 41, 1-8. [CrossRef]

63. Brinate, S.V.B.; Martins, L.D.; Pereira Rosa, G.N.G.; Cunha, V.V.; e Jesus Sotero, A.; do Amaral, J.F.T.; Tomaz, M.A.; de Jesus, W.C. Copper can influences growth, disease control and production in Arabica coffee trees. Aust. J. Crop Sci. $2015,9,678-683$.

64. Cristancho, M.A.; Rozo, Y.; Escobar, C.; Rivillas, C.A.; Gaitán, A.L. Outbreak of Coffee Leaf Rust (Hemileia vastatrix) in Colombia. New Dis. Rep. 2012, 25, 19. [CrossRef]

65. Cook, R.T.A.; Pereira, J.L. Strains of Colletotrichum coffeanum, the causal agent of Coffee Berry Disease, tolerant to benzimidazole compounds in Kenya. Ann. Appl. Biol. 1976, 83, 365-379. [CrossRef]

66. Aktar, W.; Sengupta, D.; Chowdhury, A. Impact of pesticides use in agriculture: Their benefits and hazards. Interdiscip. Toxicol. 2009, 2, 1-12. [CrossRef]

67. Capucho, A.S.; Zambolim, L.; Lopes, U.N.; Milagres, N.S. Chemical control of Coffee Leaf Rust in Coffea canephora cv. Conilon. Australas. Plant Pathol. 2013, 42, 667-673. [CrossRef] 